\title{
Occupational asthma, rhinitis, and dermatitis due to tetrazene in a detonator manufacturer
}

\author{
P SHERWOOD BURGE, M HENDY, ES HODGSON
}

From the Department of Thoracic Medicine, East Birmingham Hospital, and IMI (Kynoch) Ltd, Birmingham

The detonation of sporting ammunition requires a guaranteed method of igniting a small quantity of percussion sensitive mix contained in a metal chamber known as a cap. This is struck externally by the firing pin. Mercury fulminate, used originally, is highly toxic and unstable. Manufacturers in modern times have therefore based the ignition mixture on the lead salt of trinitro resorcinol (styphnic acid). A typical mixture also contains oxidisers, fuel (to provide a good heat output), and tetrazene as a sensitiser. Percussion caps must fire with absolute reliability when struck by a blow of specified energy content but must not fire at lower energy inputs. To maintain fine control, tetrazene is used as a relatively weak percussion sensitive explosive in its own right. It is, however, indispensible in the industry as the only sensitiser known for lead styphnate. Its chemical name is 1-(5-tetrazoly)-4-guanyltetrazene hydrate and it is synthesised from organic salts of amino guanidine. The commercial product with which this paper is concerned is an off white fine powder of low bulk density in short needle crystals of a wide range of sizes. It is stable when submerged in water at ordinary temperatures but is rapidly destroyed by boiling water. The dry powder is a highly sensitive explosive but can be handled safely if sufficiently diluted in inert materials. It is practically insoluble in all common solvents but it can form salts with strong mineral acids. It is decomposed by strong bases such as sodium hydroxide.

\section{Case report}

A 51 year old fitter had been working for the same company for 27 years. In October 1980 he started working on the development of a machine to charge percussion caps with an explosive mixture. The work required the testing of the machine with both dummy and "live" mixtures and making subsequent modifications to the machine. He loaded the powders by hand into the machine. Much of the work had to be done before the machine was enclosed, resulting in much greater exposures than would occur during normal use. The machine handled a relatively nonexplosive powder containing tetrazene, lead monoxide, lead dioxide, antimony sulphide, styphnic acid, barium nitrate, calcium silicide, and geranine red dye. The mixture was dispensed into caps. Wetting the mixture led to the

Address for reprint requests: Dr P Sherwood Burge, Solihull Hospital, Solihull, West Midlands B91 3AH.

Accepted 10 January 1984 formation of lead styphnate, resulting in a highly explosive mixture when it was subsequently dried.

The patient first became ill in February 1981, when he developed breathlessness during the night and on waking in the morning on days which followed use of the detonator mixture at work. He had no definite exercise induced asthma but was mildly breathless between these attacks. He then developed a severe episode of chest tightness and rhinitis, which did not improve with antibiotic treatment
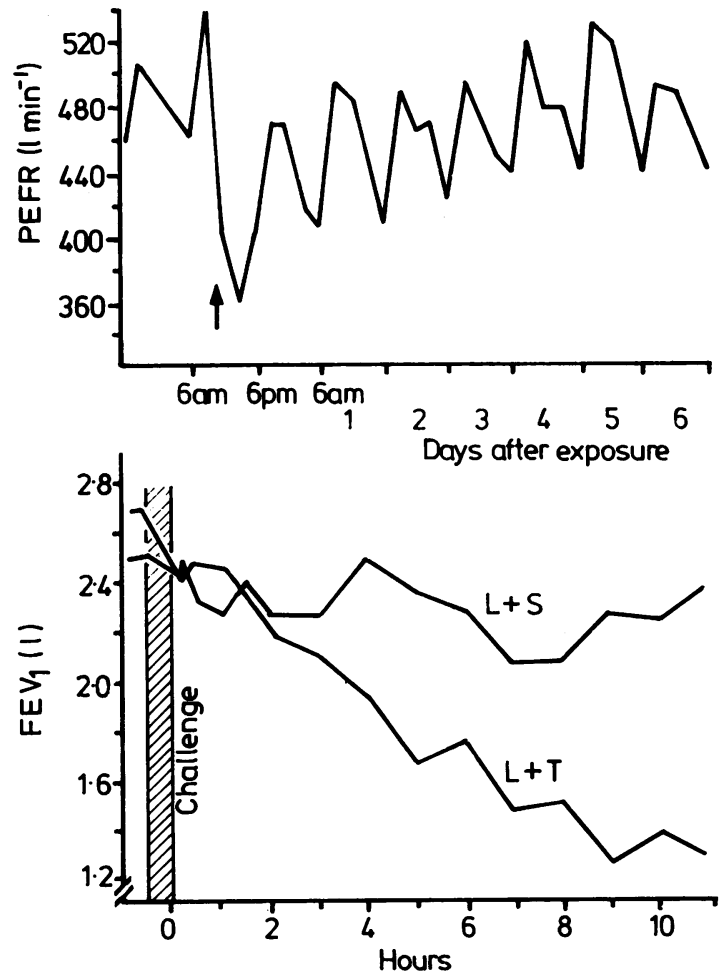

(a) Four hourly peak flow readings before and after exposure to tetrazene (arrow), showing an asthmatic reaction lasting for at least seven days afterwards. (b) Results of bronchial provocation testing with lactose plus styphnic acid $(L+S)$ and lactose plus tetrazene $(L+T)$, showing a late asthmatic reaction following the tetrazene exposure. 
Table 1 Details of bronchial provocation testing

\begin{tabular}{llllll}
\hline Day & $\begin{array}{l}\text { Challenge } \\
\text { material }\end{array}$ & Starting $F E V_{1}(l)$ & $\begin{array}{l}\text { Duration of } \\
\text { challenge (min) }\end{array}$ & $\begin{array}{l}\text { Immediate reaction: } \\
\text { maximum fall } \\
\text { in } F E V_{1}(\%)\end{array}$ & $\begin{array}{l}\text { Late reaction: } \\
\text { maximum fall } \\
\text { in } F E V_{1}(\%)\end{array}$ \\
\hline 1 & $\begin{array}{l}\text { Tetrazene 6.5\% with lead monoxide, } \\
\text { lead dioxide, and antimony sulphide }\end{array}$ & $2 \cdot 69$ & & 35 \\
2 & $\begin{array}{l}\text { Lactose 500 g and styphnic acid } 5 \mathrm{~g} \\
\text { Lactose and 6.5\% tetrazene }\end{array}$ & $2 \cdot 51$ & 30 & 9 & 52 \\
4 & $\begin{array}{l}\text { Lead monoxide, lead dioxide, and } \\
\text { antimony sulphide }\end{array}$ & $2 \cdot 61$ & 30 & 8 & 9 \\
\hline
\end{tabular}

while he remained at work but improved within a week of his taking time off work. On returning to work in April 1981 he developed eczematous lesions in the corners of his mouth, in his elbow creases, behind his ears, and on his hands, with swelling around his eyes. $\mathrm{He}$ also became breathless, waking at night with cough and wheeze. All symptoms improved considerably with a week off work. He had smoked 20-40 cigarettes a day previously, and had had dermatitis related to a washing powder. There was no history of childhood chest diseases or wheezing. Measurement of lung function (including measurements of gas transfer) when he was away from work yielded normal results. There was no blood or sputum eosinophilia. Skin testing with common environmental allergens gave negative results. The total serum IgE concentration was $520 \mathrm{IU} / \mathrm{ml}$ and the blood lead concentration was $1.5 \mu \mathrm{mol} / \mathrm{l}(31.05 \mu \mathrm{g} / 100 \mathrm{ml})$.

Bronchial provocation tests were carried out on separate days at least a week apart. The constituents were used as a dry powder and tipped between two trays. This process was done very carefully because of the explosive nature of the materials. There was a strong late asthmatic reaction after exposure to the submix containing tetrazene, lead monoxide, lead dioxide, and antimony sulphide. This reaction continued for a week (fig). There was no appreciable reaction to the submix without tetrazene. Exposure to $6.5 \%$ tetrazene in lactose resulted in a late asthmatic reaction lasting at least a week (fig). There was no appreciable reaction when styphnic acid $(5 \mathrm{~g})$ was added to $500 \mathrm{~g}$ of lactose (producing a similar concentration of styphnic acid to that present in the premix used at work). Details of the tests are shown in the table. Dust concentrations in the breathing zone were monitored only during the fourth test day as the explosive nature of the mixtures on the other days precluded the use of electrical sampling devices. Total particulates collected on a membrane filter were $2.1 \mathrm{mg} / \mathrm{m}^{3}$ measured $15 \mathrm{~cm}$ from the mouth, the relatively high weight of the mixture being due to the lead it contained.

\section{Discussion}

This man had classical symptoms of occupational asthma, with attacks coming on in the evening and at night after work. After continued exposure he developed symptoms suggestive of bronchitis, which cleared when he was away from work. He also had rhinitis and particularly severe dermatitis after exposure. His dermatitis cleared completely within a month of leaving work. At the onset of the investigations styphnic acid was though to be the most likely cause of the occupational asthma as several workers complained of sneezing on contact with this chemical. It is also possible that the dye, used to indicate the dryness of the mixture, was a cause of the asthma. Differential bronchial provocation tests, however, clearly showed that the reaction was solely due to tetrazene.

Tetrazene is likely to have behaved as an allergen in view of the extreme sensitivity seen and the coexistence of dermatitis and asthma, the latent interval between exposure and first symptoms, and the raised IgE concentration in the absence of any positive response to testing with common environmental allergens.

Our thanks are due to Dr G Carter for preparing the materials for challenge testing. 